\title{
Surogaty tożsamości wobec genealogii i rozwoju podmiotu. Pomiędzy mimetyczną funkcją anamorfozy a figurą Innego ${ }^{1}$
}

Fantazmat fabrykowania bytu ludzkiego (klonowanie reprodukcyjne) wynika ze scjentyzmu, z wyobraźni naukowej, czego w aktualnych warunkach nie ma powodu się obawiać. Nawet jeśli technicznie taka reprodukcja jest możliwa, to statut klona nie będzie taki, jak dzisiaj sobie wyobrażamy, doktadnie dlatego, że aby istnieć, klon będzie musiat być podmiotem i odnaleźć osobliwa tożsamość

(Derrida i Roudinesco, 2016, s. 80)

Streszczenie: Tożsamość jest jedną z kluczowych kategorii, która z uwagi na zmiany kulturowe, światopoglądowe czy ideologiczne uzyskała swoiste reprezentacje interpretacyjne w dyskursach oraz przestrzeni społecznej. Zmiany te skłaniać powinny do refleksji nad dotychczasową percepcją, a także recepcją fundamentalnych kategorii pozwalających zrozumieć, czym współcześnie jest tożsamość i jakie jest jej osadzenie w źródłach podmiotowości rozumianej w perspektywie wykładni Heideggerowskiego bycia-w-świecie (Dasein) czy Lacanowskiego pragnienia oraz relacji do Innego. Egzemplifikacja tych ontologicznych i fenomenologicznych reprezentacji nie jest przypadkowa, nie jest też wyborem dyskursu nazywanego z nieukrywaną dziś dezaprobatą - postmodernistyczną manierą uznawaną w swej ignorancji za (post)prawdę. Wyłonienie przedstawianych w tekście fenomenów kulturowych jest celowym ukazaniem spektrum takiego rodzaju hermeneutyki, która pozwala na uwzględnienie współczesnego rozumienia człowieka jako bytu uwikłanego w postęp technologiczny, określanego przez interes poznawczy $\mathrm{i}$ jed-

1 W tekście posługuję się pojęciami zaczerpniętymi z psychoanalizy Jacquesa Lacana, stosując specyficzny zapis pojęć, które odnoszą się do matemów zastosowanych w topologii. Z tego powodu wszystkie pojęcia Lacanowskie zapisane są kursywą i jeżeli są matemami, pisane są dużą literą. W polskich tłumaczeniach Lacana zastosowano inny zapis, ale dla czytelności tekstu pozostaję przy zapisie, którego używałam w swoich publikacjach dla podkreślenia odmienności pojęciowej między tym, co jest specyficzne dla psychoanalizy Lacana, a co należy do innych dyskursów (Węc, 2012, 2015). 
nocześnie poddanego konieczności emancypacyjnej jako niezbywalnego prawa jednostki wyznaczającego jej miejsce w świecie i dla świata. Z drugiej strony mamy do czynienia z podmiotem, który niezmiennie uwikłany jest we własną historię rodzinną, lęki egzystencjalne czy jednostkowe kompleksy wynikające z nieadekwatności wobec otaczającej rzeczywistości i niepewnych relacji z Innym.

Słowa kluczowe: pedagogika, psychoanaliza Lacanowska, podmiot, tożsamość, rozwój, fenomeny kultury, edukacja międzykulturowa

\section{Wprowadzenie}

Dylematy współczesnego człowieka wyznaczają pytania o aktualizację rozumienia jego statusu w świecie, jego potencjalności rozwojowych oraz identyfikacji kulturowych. Niezmiennie wpisując się przy tym w fundamentalną troskę formułowaną na poziomie myśli filozoficznej, diagnozy psychologicznej i to, co najbardziej interesuje pedagoga - na poziomie oddziaływania wychowawczego. Zadziwiać może, że wbrew oczywistemu przedmiotowi badań pedagogicznych wciąż słyszalne są zarzuty wobec podejmowanej problematyki dotyczącej podmiotowości, tożsamości i rozwoju - ponoć wyznaczanych przez nadmiernie eksponowany w naukach społecznych lejtmotyw. Tym niemniej tekst, który proponuję czytelnikowi, wyznacza alternatywne spojrzenie na to, co w naukach społecznych a priori uznać można za lejtmotyw, czy jak powiedziałabym za Zbigniewem Kwiecińskim, Bogusławem Śliwerskim czy Lechem Witkowskim - za puste, wyzerowane kategorie, na które nie ma pedagogicznej zgody. Jeżeli bowiem lejtmotywem jest podmiotowość, tożsamość, rozwój, nie wspominając o wciąż nieuzasadnionych obawach przed emancypacją - to właściwie możemy zlikwidować jako dyscyplinę naukową pedagogikę, socjologię, psychologię, nie wspominając o filozofii.

Z perspektywy pedagoga i psychoanalityka Lacanowskiego, którym jestem - chciałabym oczywiście, żeby koncepcja podmiotu Lacana stała się lejtmotywem nauk społecznych, co niewątpliwe ma w pewnym sensie miejsce we współczesnych dyskursach kultury - czego w Polsce nie chcemy zauważyć. W kulturze europejskiej psychoanaliza Lacanowska jest znaczącym dyskursem ustanawiającym paradygmat postrukturalistycznego rozumienia kultury. Upraszając problem, zaznaczam, że chodzi o recepcję postrukturalizmu przenoszącą nas w perspektywę odmiennego rozumienia dyskursu, który po przewrocie językowym pozwala na rozróżnienie znaczenia od znaku, uka- 
zując, że sens interpretacji będzie wyznaczany przez przyjęty przez badacza paradygmat hermeneutyczny (Rasiński, 2009; Węc, 2015a). W równej mierze chciałabym, żeby rozumienie Lacanowskiego Innego nie wywoływało u pedagogów nieustającego domagania się odniesień do koncepcji Levinasa, czy kogokolwiek innego, kto podejmował rozważania na temat kategorii Innego. Levinas i Lacan prowadzą dwa odmienne dyskursy o Innym (Węc, 2008) o czym napisano tak wiele teksów kulturowych, że wystarczy po nie sięgnąć, by nie sprowadzać każdego tekstu do poziomu rozważań podstawowych prowadzonych na salach wykładowych dla studentów. W tym również sensie emancypacja, o którą się upominam, ma wymiar rozwojowy i wymiar nadania prawa do wyboru paradygmatu badawczego. Chodzi o to, by recenzent, czy nauczyciel nie przybierał pozycji Innego-Cenzora zajmującego - w swym fenomenie kulturowym - miejsce Figury określonej przez Foucaulta przez aporie władzy i wiedzy. Nie odbierajmy sobie prawa do wyboru rodzaju dyskursu, nawet jeżeli ma on swoje źródło w pozornie obcej kulturze. Przyjmuję, że jest to dyskurs nieobecny z uwagi na różnice światopoglądowe oraz wybór paradygmatu pozytywistycznego, który zdominował współczesne nauki społeczne. Różnice te nie powinny jednak prowadzić do wykluczania dyskursów obcych kulturowo bądź niepopularnych badawczo. W konsekwencji chodzi o to, by nie myśleć o człowieku jedynie w perspektywie jego adaptacji do systemu przy jednoczesnym ujawnianiu lęku generującego poglądy, że emancypacja wyklucza budowanie ładu społecznego. Proponowana przeze mnie perspektywa Lacanowskiego rozumienia podmiotu oraz Innego pozwala mi przyjąć założenie, że adaptacja jest procesem ograniczającym rozwój podmiotu oraz kształtowanie jego tożsamości zarówno indywidualnej, jak i społecznej. W tym też sensie kwestia emancypacji podmiotu dotyczy nadania mu prawa do... posiadania prawa... do prawa: wyboru, wolności, światopoglądu, słowa, seksualności, czy wreszcie rozumienia własnego rozwoju w takim znaczeniu, jaki jest dla podmiotu istotny. Emancypacji nie można mylić z anarchią czy też różnymi rodzajami anomii, heterotopii, heterologii, transgresji czy utopii ${ }^{2}$. Martwić może, że mimo znacznego rozwoju nauk społecznych, bez względu na to, czy przedmiot badań będzie interpretowany z wnętrza pedagogiki, socjologii, czy psychologii, wciąż patrzymy na człowieka z perspektywy jego adaptacyjnej powinności i nieuzasadnionej obawy

2 Problem ten szczegółowo analizuję w książce Granice i transgresje wspótczesnego wychowania. Psychoanaliza wobec kryzysu podmiotu w rozdziale Graniczność jako podstawa transgresyjności nauk humanistycznych (Węc, 2015, ss. 44-56). 
przed dążeniami emancypacyjnymi. Oczywiście domniemanie lejtmotywu ma pewne uzasadnienie, ale raczej z perspektywy myślenia o tych trzech kategoriach, które stają się „pustymi znaczącymi”, które zamiast budzić refleksję - powtarzane są jak mantra, której nikt nie rozumie.

Nie jest przecież tajemnicą, że od czasu rozwoju badań antropologicznych - rozwój człowieka zawsze polegał „na stopniowym krystalizowaniu się określonych instytucji z rozmaitych niewyspecjalizowanych zachowań" (Malinowski, 2000, s. 34). Z drugiej strony, warto pamiętać dzieło Marcuse przekonującego nas, że rozwój kultury wyznaczającej jednocześnie rozwój systemu prowadzi do ukonstytuowania człowieka jednowymiarowego, skutecznie przy tym tłumiąc rozwój tych możliwości ludzkiej natury, które są niezgodne z rozumem technologicznym. W tym sensie możemy powiedzieć, że społeczeństwo technologiczne wykazuje wielką zdolność do cywilizacyjnego rozwoju, do obrony i utrwalania fundamentów swego systemu - aczkolwiek dzieje się tak kosztem jednostki, zachwiania jej fundamentów podmiotowości, a w ostateczności odebrania poczucia pierwotnie ukonstytuowanej tożsamości - na rzecz tożsamości pożądanej społecznie (Por. Marcuse, 1991). Tym, co wydaje się najbardziej interesujące w ukazanej dialektyce - jest dążenie do uzyskania podmiotowej samowiedzy, osiągnięcie odpowiedniego poziomu samorozwoju i oczywiście uzyskanie dostępu do tego rodzaju samoświadomości, która będzie zgodna z interesem społecznym, uformowanym przez system i systemowi temu będzie podporządkowana. Tak przyjęta perspektywa interpretacyjna nie jest pozbawiona refleksji, że interes społeczny nakazuje zachowanie pewnej ostrożności wobec wszelkiej dialektyki, która mogłaby potencjalnie promować myśl groźną w kontekście promowania kultu jednostki unikającej zewnętrznych zależności i uwikłań pozapodmiotowych. Biorąc również pod uwagę perspektywę historyczną, warto pamiętać, że Heglowska samowiedza oraz rozwój ducha pozwala dostrzec człowieka uformowanego przez kulturę jako podmiot niszczący oraz negujący wszystko, co lokuje byt w rozmaitych formach pracy i walki. Można zatem uznać, że uzyskana przez podmiot zdolność do negacji określa zarówno istotę człowieka, jak i dialektyczną zasadę wyrażaną przez Lacana, że czyny podmiotu reprezentowane są poprzez dialektykę ujmowaną przez doświadczenie przebiegające w cyklu: od słowa - przez akt - ku słowu. W tym właśnie sensie szczególną wartość dla pedagogów wyznacza myśl fenomenologiczna wyjaśniająca „rozwój samowiedzy pojmowanej antropologicznie, trochę w kategoriach Marksa (jako praca) oraz trochę w kategoriach wczesnego Heideggera (jako bycie-w-świecie, bycie-ku-śmierci)" (Gusin, brw) - 
pozwalająca na spojrzenie na rzeczywistość jednostki nie tylko z perspektywy jej funkcjonalnej wartości, ale również poprzez pryzmat jej ontologicznej niedookreśloności.

To dialektyczne uwikłanie nie pozostaje oczywiście bez znaczenia dla samego człowieka, co jaskrawo uwypuklił znany polski psycholog Kazimierz Dąbrowski, przyjmując za podstawę swojej teorii dezintegracji pozytywnej, że „rozwój psychiczny człowieka nie przebiega harmonijnie i bezboleśnie, lecz jest dramatem, w którym nie brakuje ciężkich momentów zagubienia, dezorientacji, zwątpienia i smutku" (Dąbrowski, 1989). Potwierdzają to również psychologiczne badania grup społecznych, ukazujące, że „psychologia grupy jest historią kompromisu między potrzebami jednostki i społeczności, podobną do mechanizmu określanego przez Annę Freud mianem identyfikacji z agresorem. Tego rodzaju wewnętrznie konfliktowe procesy widoczne są w szczególności w dużych grupach, w których biurokracja i organizacja w szczególny sposób pośredniczą między jednostką i społecznością. W tych zbiorowościach takie psychologiczne obrony, jak pokawałkowanie komunikacji umożliwiające specjalizację ról społecznych, mogą zahamować rozwój emocjonalny i uczenie się jednostki" (Szałek, 2002, s. 243). Problem ten rozpoznaje także niemiecki filozof Hans-Georg Gadamer, który uważa, że rozwój „coraz bardziej przybiera formę panicznej ucieczki przed wolnością”, co w efekcie „zaostrza problem, w jakiej mierze nauka sama powinna przejmować współodpowiedzialności za następstwa swych zastosowań”, gdyż „żaden rozwój wiedzy nie jest, jeśli chodzi o jej znaczenie i następstwa, przewidywalny" (Gadamer, 2008). Nie można pominąć wśród narracji zbudowanych wokół miejsca, znaczenia i wartości podmiotowości w aspekcie wyznaczania sensu jego bytu - współczesnego socjologicznego aspektu dialektycznej równicy między Giddensowskim działaniem (agency) a strukturą (structure) w rozumieniu Pierre Bourdieu. W tym wypadku teoria strukturacji, sytuując się w opozycji do konstruktywizmu strukturalnego, ukazuje ontologiczny dylemat pomiędzy uznaniem pierwszeństwa działania nad znaczeniem w wyjaśnianiu ludzkiego zachowania a funkcjonalnym założeniem o prymacie „struktury” pozostającej ponad działaniem.

Ostatecznie możemy postawić pytanie: Jak w ontogenetycznym i filogenetycznym rozumieniu rozwoju ogniskować problematykę wokół rozumienia istoty podmiotowości bez stosowania reguł uprzedmiotawiających człowieka w jego relacji do Innego? Odpowiedź na to pytanie jest o tyle trudna, o ile sama idea podmiotowości została dalece zinfantylizowana i ograniczona przez instytucjonalną funkcjonalność podporządkowaną interesowi spo- 
łecznemu, kulturowemu, a także niestety politycznemu. Z tego też powodu odmiennego znaczenia nabiera egzemplifikacja dyskursów nawiązujących do życzeniowego myślenia o niezakłóconym niczym rozwoju. Nie dzieje się to jednak bez podmiotowych konsekwencji, gdyż równocześnie zostają wygenerowane społeczne narracje wywołujące poczucie lęku na samą myśl o potencjalnym ryzyku wyznaczanym przez symboliczne i wyobrażeniowe reprezentacje ukazujące podmiotową niewystarczalność i nieadekwatność wobec roszczeń stawianych przez Innego. W tym sensie rozumienie rozwoju jako swoistego fenomenu zawłaszczającego dyskurs społeczny w jego symbolicznym wymiarze ukazuje rzeczywistość podmiotową jako zniewoloną przez działanie Innego, który może być zarówno kreatorem tego procesu, jak i jego manipulatorem.

\section{Od rozwoju kultury do rozwoju podmiotu - od rozwoju podmiotu do rozwoju kultury}

Jak już wcześniej zostało powiedziane, rozwój stał się podstawą dyskursów społecznych, zarówno tych profesjonalnych, przez pedagogikę, psychologię czy filozofię, jak i tych znajdujących się w ogólnej przestrzeni społecznej. Pytanie o intensywność i zakres rozwoju wyznacza kierunek wszelkich rozważań dotyczących człowieka oraz określa apriorycznie sens jego istnienia. $\mathrm{Z}$ jednej strony rozwój uznaje się za naturalny proces, któremu jednostka bezwzględnie jest poddana, z drugiej rozwój stał się wymogiem kulturowym prowadzącym potencjalnie do stygmatyzacji oczekiwań wobec każdego bez względu na jego pragnienie poddania się takiej zmianie. Człowiek został schwytany w pułapkę bycia doskonałym, ulegając społecznie konstruowanej narracji mającej w założeniu prowadzić do sformatowania tożsamości poprzez wymóg aktywności, kreatywności, a nade wszystko twórczości (Witkowski, 2009, 2015). Opór przed taką pozorną identyfikacją staje się aktem społecznie ryzykownym - pomimo że, jak się wydaje, wyraźnie mylony jest potencjał rozwoju biologicznego (fizycznego) z możliwościami rozwoju poznawczego (intelektualnego), a przede wszystkim z dynamiką konstytuowania się podmiotu również w odniesieniu do nabywania przez niego dojrzałości etycznej. W rzeczywistości uaktywniony zostaje pewnego rodzaju mit założycielski, w którym pierwsze skrzypce odgrywa metafora „klonowanej tożsamości". Tożsamości reprezentującej semantyczną figurę asymilującą narcystyczne identyfikacje jednostki o charakterze wyobrażeniowym, które ograniczają identyfikacje symboliczne. Dopiero wtedy, gdy podmiot poradzi 
sobie z identyfikacjami wyobrażeniowymi, może przyjąć kulturowe wartości symboliczne stojące w sprzeczności z rozwojem rozumianym jako metaforyczne klonowanie społecznych potrzeb.

W tym sensie zarówno „doskonałość” biologiczna, jak i społeczna, mimo że współcześnie stały się mitami założycielskimi „społeczeństwa wiedzy i sukcesu" - a zatem specyficznie rozumianego rozwoju - są jedynie fantazmatycznymi narracjami niewiele różniącymi się od wierzeń ludycznych ujętych w ramy antropologicznego rozumienia. Ujawnia się tu bowiem swoisty rodzaj myślenia magicznego odsłaniający ambiwalentność i zarazem niemożliwość realizacji naiwnego życzenia wyrażanego poprzez równoległe generowanie potrzeby rozwoju i braku ryzyka z nim związanego. Warto jednak mieć na uwadze, że nie chodzi o potoczne rozumienia ryzyka jako czynnika bądź wskaźnika rzekomo przynoszącego straty - ani w odniesieniu do teorii decyzji, ani w stosunku do zarządzenia projektami społecznymi. Problemem staje się powszechne przekonanie o konieczności podejmowania działań wykluczających ryzyko i zapobiegających jego nieoczekiwanym skutkom. Oczywiście natychmiast rodzi się pytanie - w jaki sposób należy oceniać i mierzyć domniemanie wystąpienia ryzyka - zwłaszcza że wydaje się, że mamy bardziej do czynienia z pewnym wymiarem spekulacji niż z rzeczywistym wynikiem poznania. Faktycznie stykamy się ze spektrum rozmaitych narracji podporządkowanych instrumentalnemu rozumowi nakazującemu poszukiwanie znaczacych ${ }^{3}$ określających granice ryzyka. W efekcie skategoryzowane zostaje pożądane doświadczenie wychowawcze i rzeczywistość podmiotowa - bez określenia granic rozwoju, gdyż takich potencjalnie ponoć nie powinno być. W dyskursie społecznym zinternalizowana zostaje zracjonalizowana narracja instrumentalizująca podmiot w jego działaniu - a nawet w jego bycie (bytowaniu - jak powiedziałby Heidegger). Podmiot powinien być zatem taki, jakiego wymaga zunifikowane społeczeństwo, jego tożsamość musi nosić znamiona identyfikacji z mitem założycielskim społeczeństwa wiedzy, a egzystencja pozbawiona immanentnych wartości samopoznania ma służyć zyskowi zracjonalizowanego społeczeństwa. Racjonalność staje się tu jedynie narzędziem, które ma służyć do wypełniania misji w realizacji mitu założycielskiego. Jednak odwołując się do interpretacji psychoanalitycznej, można przyjąć, że różne kategorie racjonalności są możliwe jedynie wtedy, gdy uwzględniają istniejącą sferę (nie)racjonalności, która dla podmiotu

3 Dla Lacana, wyrastającego z tradycji strukturalistycznej, znaczone (sens) jest praktycznie funkcją relacji między znaczącymi (Dybel, 2005, s. 19). 
może być wynikiem działania wypływającego z porządków Nieświadomego bądź Realnego ${ }^{4}$. Skutkiem tego zawsze podejmowane będą próby znoszenia ustalonych granic, a co za tym idzie - pojawiania się obszarów (trans)granicznych, które ujawniać mogą pewien rodzaj doświadczenia transgresyjności niosącego nadzieję na rozwój lub ryzyko regresji. Konstytuowanie się podmiotu w procesie jego wzrastania będzie nabierać cech „indywidualnego mitu” przybierającego formę „indywidualnych koncepcji”, w ramach których każdy z nas doświadcza świata na swój sposób.

W kontekście pedagogicznej refleksyjności racjonalność okazuje się „koncepcją" w metaforycznym, a nie dosłownym znaczeniu, a to pozwala uznać, że znaczącymi stają się (nie)uświadamiane kategorie, założenia i reguły kierujące szeroko rozumianą rzeczywistością podmiotu (Kwaśnica, 2007, s. 9). Pojawiają się tutaj dwa ważne obszary oddziaływań: pierwszy dotyczy indywidualnych doświadczeń podmiotu, płynących z wyraźnie odczuwalnego napięcia, mającego swoje źródło również w szerokim rozumieniu doświadczenia społecznego; drugi odnosi się do praktycznego powołania pedagogiki, którego celem jest stwarzanie nauczycielom, wychowawcom i terapeutom możliwości rozumienia uwarunkowań własnego działania oraz ujawnianie tych wymiarów procedur edukacyjnych, które przesłonięte są przez wszelkiego rodzaju stereotypy myślowe (Kwaśnica, 2007, s. 12). Wartością samą w sobie staje się zatem symboliczny wymiar dyskursu i praktyki uwzględniającej zdarzenia graniczne wyznaczające trudności w relacjach interpersonalnych, pozwalając na wprowadzenie zmian zarówno na poziomie funkcjonowania ucznia, jak i działania nauczyciela. Celem staje się odkrywanie takiego systemu myślowego ujmującego doświadczenie ludzkie w perspektywie pozwalającej uchwycić podstawowe wyznaczniki decydujące o jego egzystowaniu jako całości. W tym sensie język psychoanalizy daje szansę na odnalezienie znaczenia określającego doświadczenie podmiotu, które przesąadza o sposobie rozumienia świata oraz umożliwia rozróżnienie „głębokiej (nie w pełni uświadomionej) struktury doświadczenia od struktury powierzchniowej" (Kwaśnica, 2007, s. 20). Zasadniczą kwestią staje się zrozumienie relacji podmiotu do przedmiotu, gdyż przedmiot istnieje dzięki podmiotowi, ale zarazem jest przez podmiot stwarzany w zależności od sposobu jego widzenia. W takim znaczeniu możemy osadzić również to, co chcielibyśmy zoba-

4 Lacan sformułował koncepcję trzech porządków psychicznych, przyjmując, że porządek Wyobrażeniowy jest miejscem dochodzenia do sensu, porządek Symboliczny jest polem dwuznaczności, a Realne jest miejscem wszystkiego, co jest niemożliwe do pomyślenia (Węc, 2013, ss. 227-237). 
czyć jako efekt działań pedagogicznych, gdzie wychowanie wyznacza swoisty przedmiot naszych starań, które będą bądź nie - znaczące dla podmiotu. Mamy tu do czynienia z sytuacją, gdy ujawniają się granice możliwej widzialności świata ustanawiające pytanie o struktury sensotwórcze oraz struktury uobecniania przez podmiot wszelkiego bytu wobec świata, Innego i siebie. Racją stanu dla pedagogów staje się umiejętność sformułowania pytań: W jaki sposób człowiek tworzy swój świat? Co czyni ten świat sensownym? Co konstytuuje znaczenie dla podmiotu? W jaki sposób to wszystko określa granice jego doświadczenia? W szerokiej perspektywie edukacyjnej chodzi zatem o umiejętność dostrzeżenia człowieka i jego podmiotowego sposobu bycia pozwalającego nadawać sens obecnym w polu życiowym przedmiotom i zdarzeniom, określając granice możliwej widzialności świata poprzez wyznaczanie struktury rzeczywistości dostępnej doświadczeniu. Struktury sensotwórczej określającej granice i sposób interpretacji (rozumienia) świata przez podmiot, konstytuującej refleksję o tym, co poprzedza i umożliwia doświadczenie podmiotu, nadając kształt jego rzeczywistości (Kwaśnica, 2007, Ss. 22-26).

Powrócę jednak do tezy, że racjonalność nie istnieje bez (nie)racjonalności, co oznacza, że w odniesieniu do procesów rozwojowych dziecka może być ona rozpatrywana jako wyobrażeniowość sformułowana na potrzeby użyteczności edukacyjnej. W takim rozumieniu zakładamy u dziecka zaistnienie gotowości do „bycia wychowywanym” którą podmiot potencjalnie osiągnie, dając na to przyzwolenie Innemu - albo nie osiągnie i nie wyrazi zgody na uruchomienie jakichkolwiek działań mających „ucywilizować jego naturalne popędy" (Nalaskowski, 2009). Będzie to uzależnione od procesów identyfikacyjnych i mechanizmów separacyjnych, które zadziałają bądź nie. Jako rodzice czy wychowawcy znajdujemy się na poziomie zakładanego podmiotu wiedzy - będącego w rzeczywistości podmiotem (nie)wiedzy podporządkowanym działaniu przeniesienia wyznaczającego naszą iluzję . Przyjmujemy zatem, że na gruncie działań wychowawczych rzeczywistość podmiotu określana jest przez co najmniej dwie kategorie konstrukcji myślowych: Wyobrażeniowej w odniesieniu do racjonalności i (nie)racjonalności oraz Symbolicznej wyrażanej poprzez język, który wcale nie musi reprezentować wartości komunikacyjnych. Funkcja Symboliczna nie wyznacza również

5 Pisał o tym na początku XX wieku Oskar Pfister, podkreślając powszechność występowania oraz znaczenie przeniesienia, które uważa za niezbędne w praktyce pedagogicznej (Pfister, 1931). 
sposobu interpretacji doznań podmiotowej rzeczywistości, ale ustanawia to, co metaforycznie możemy nazwać pierwotnymi przedmiotami prawdy - niosącymi poczucie trwogi mającej swoje źródło w doświadczeniu obecności oraz (nie)obecności Innego. Dwoistość tak wyznaczonej konstrukcji podmiotowej będzie się rozgrywać w oscylacjach: jestem - (nie)jestem; rozstrzygnięć domagania się: chcę - (nie)chcę; wreszcie poprzez pragnienie ujawniające się jako nadmiar bądź brak ${ }^{6}$. Psychoanaliza wnosi nam trzeci wymiar funkcjonowania podmiotu, który nie znajduje miejsca ani w dyskursie pedagogicznym, ani w praktyce wychowawczej, gdyż odnosi się do tego wszystkiego, co dla podmiotu wnosi trwoga (Lacanowskie Encore) ujawniająca się pod wpływem (nie)jawnej obecności Realnego. Dla pedagogiki właśnie to Realne niesie ze sobą różnego rodzaju transgresje oraz wszystko to, co u podmiotu budzi trwogę, gdyż nie istnieje możliwość wykluczenia przypadkowości zdarzenia. Działanie Realnego, którego pedagodzy nie chcą dostrzec, reprezentuje równocześnie wszelkie aspekty (nie)wyobrażalnego, (nie)przewidywalnego, (nie)reślonego, niosącego znamiona heterologiczności oraz wprowadzającego niepokój w myślenie o wychowaniu.

W tym właśnie kontekście, myśląc o rozwoju, trudno pominąć to, co określa nam dialektyczne konstytuowanie się podmiotu oraz nabywanie tożsamości, która w żaden sposób nie może zostać wyalienowana z wieloaspektowych procesów identyfikacyjnych. Przyjmujemy, że istotą rozumienia działań pedagogicznych staje się uwzględnienie samego podmiotu w jego byciu i pragnieniu - również poza procesami socjalizacyjnymi, które nierzadko warunkowane są przez zinstrumentalizowane interesy społeczne. Nie ulega wątpliwości, że zarówno rozumienie podmiotowości, jak i procesu nabywania tożsamości wymaga reinterpretacji ${ }^{7}$. Zwłaszcza gdy w przestrzeni praktyki pedagogicznej obie te kategorie zostały zinfantylizowane i sprowadzone do pustych znaczących mających usprawiedliwiać wszelkie działania kreujące jakiś potencjalny rozwój podmiotu i wywoływać pożądaną społecznie tożsamość. W trosce o rzeczywiste rozumienie procesów rozwojowych musimy zmierzyć się z dwoma najważniejszymi pytaniami, które dotyczą człowieka - jak konstytuuje się podmiot? oraz jaki jest proces nabywania tożsamości?

6 Recepcji kategorii dwoistości w pedagogice dokonał między innymi Lech Witkowski (Witkowski, 2013, 2001).

7 Z uwagi na charakter tekstu nie odnoszę się do znanych prac Zbyszko Melosika, Tomasza Szkudlarka oraz Lecha Witkowskiego, które od wielu lat wyznaczają w polskiej pedagogice kierunek dyskursu o tożsamości i rozwoju. (Melosik, 1998, 1996, 2014; Melosik i Szkudlarek, 2013; Witkowski, 1988, 2015). 
Uwzględniając paradygmat psychoanalizy Lacanowskiej, wiemy, że podmiot konstytuuje się w przestrzeni porządku Symbolicznego, gdy tymczasem tożsamość przynależy do porządku Wyobrażeniowego. Założenie to ma istotne znaczenie w perspektywie pedagogicznych strategii prorozwojowych, by nie ulegać instrumentalnemu rozumieniu tego, co jednostka może i ma robić. Przywołując Lacana, wyraźnie widzimy, że niemożliwe jest zintegrowanie dyskursu Nieświadomego ze świadomością, ale ten francuski psychoanalityk otwiera perspektywę dla całkiem nowego myślenia o genealogii ludzkiej tożsamości, do czego później nawiążą w swoich koncepcjach tacy autorzy jak Deleuze czy Derrida (Dybel, 2005, ss. 12-17). Pamiętając o tym, że sens Lacanowskiej psychoanalizy ma inne źródło niż postfreudowskie ${ }^{8}$ interpretacje psychoanalityczne - możemy powiedzieć, że dla pedagogiki jest równie ważne, by zaprzestać działań mających na celu „wzmacnianie” Ja(ego). Istotne staje się także porzucenie przez pedagogów iluzji, że podmiot może osiągnąć pełną tożsamość z sobą samym, a co za tym idzie - przyjąć warunki nieograniczonego rozwoju nawet wtedy, gdy ładnie nazwiemy to rozwojem zrównoważonym. Alternatywną drogę wyznacza rozbudzanie świadomości i ciekawości wychowawczej w dochodzeniu do sensu podejmowanych działań poprzez problematyzację już zaprezentowanej, aczkolwiek rozwiniętej materii: czym jest dialektyka konstytuowania podmiotowości? oraz jak kształtują się procesy identyfikacyjne tożsamości? Oczywiste jest, że nie otrzymamy jasnej i jednoznacznej odpowiedzi na te pytania, niemniej jednak z tego właśnie powodu otwierają one perspektywę dającą szansę doświadczenia prawdy o sobie samym. Zadanie to jest jeszcze bardziej skomplikowane i dotyczy również tych aspektów, które pedagogicznie niechętnie podejmujemy. Odnosząc się do konstytuującego się podmiotu, musimy bowiem uwzględnić identyfikację z Innym pierwotnie poprzez kompleks Edypa, który dzięki normalizującej funkcji sublimacji pozwala określić tożsamościowe zmiany kształtu podmiotu. Freud wyraźnie wskazywał w swoich pracach, że potrzeba „topograficznej” koordynacji dynamiki psychicznej związana jest

8 Celowo również nie używam sformułowania „neofreudowskie”, by uniknąć polemiki z adwersarzami rozwoju myśli psychoanalitycznej. Oczywiście nie mam na myśli również żadnej psychoanalitycznej (post)prawdy. Zamierzeniem moim jest rozszerzenie analiz na współczesną myśl humanistyczną, z którą warto polemizować - zwłaszcza tam, gdzie odwołuje się ona do psychoanalizy i poprzez manipulację zniekształca jej pierwotny sens. Relatywizowanie paradygmatów psychoanalitycznych nie jest bowiem rozwinięciem teorii Freuda, lecz jedynie konstruowaniem dyskursu postanalitycznego, czyli w rzeczywistości nieprawdziwego. 
z wtórną identyfikacją poprzez introjekcję wyobrażenia rodzica tej samej płci. A zatem rozwój seksualny podmiotu staje się automatycznie wkomponowany w rozważania o kształtowaniu jego tożsamości.

W tym sensie możemy mieć wątpliwość, czy to, co nazywamy tożsamością płynną, wieloraką czy polimorficzną, jest w rzeczywistości jakąkolwiek tożsamością. Zaryzykuję stwierdzenie, że tożsamość - w stereotypowym bądź strywializowanym rozumieniu - jest jednie maską, którą za Lacanem możemy powiązać ze zjawiskiem mimetyzmu będącym rodzajem anamorficznego „błędu perspektywy”. Błędu pozwalającego na upodobnienie się do kogoś lub czegoś, co zewnętrznie zostaje człowiekowi narzucone (Lacan, 1981). To, co dla nas stanowi istotę rozważań, dotyczy tego, że poza Symbolicznym porządkiem języka istnieje i działa Wyobrażeniowa funkcja spojrzenia, którą warto uznać w relacji wychowawczej za równie ważną jak mówienie. Nie jest bowiem tajemnicą, że w spojrzeniu odzwierciedla się, kim podmiot jest dla Innego. Jeżeli mówienie albo spojrzenie nie zaistnieje - zbudowanie relacji z Innym może być niemożliwe. Zatem organizacja samego procesu edukacyjnego nie może być ważniejsza niż pewna wrażliwość i troska wychowawcza, w której nauczyciel musi zadbać, by ucieleśnić ideę, dzięki której dla podmiotu Inny zaistnieje poprzez konstytuowanie pragnienia podmiotu, a nie poprzez konstruowanie jego mimetycznej tożsamościowej protezy, której źródłem stał się - przywołany wcześniej - mit założycielski oparty na manii rozwoju.

Istotą tego wywodu jest założenie, że posługując się Lacanowską koncepcją konstytuowania się podmiotu dziecka, przyjmujemy zasadę, że widzi ono siebie w związku z Innym. To właśnie spojrzenie Innego daje dziecku potwierdzenie i pozwala, by uchwyciło swoje ciało jako całość, pomimo że uchwycenie to nie następuje w nim samym, lecz właśnie w spojrzeniu Innego. Dopiero wtedy podmiot uznaje, o ile otrzyma potwierdzenie od Innego, że to, co widzi w lustrze - to on. Moment ten powoduje, że podmiot zostaje uwięziony w spojrzeniu oraz mowie Innego, bowiem od kiedy spojrzenie i mówienie pojawiają się - podmiot usiłuje dostosować się do Innego i odpowiada na jego pragnienie. O tym pedagodzy muszą pamiętać, w takiej samej mierze, jak powinni uwzględniać to w podejmowanych strategiach wychowawczych. Konieczne jest również zrozumienie, że przejście przez fazę lustra ${ }^{9}$ pozwala,

9 Spotyka się różne tłumaczenia tego pojęcia - stadium zwierciadła, stadium lustra, faza lustra. Przyjmuję tłumaczenie za słownikiem psychoanalizy: faza lustra (fr. stade du miroir) (Laplanche i Pontalis, 1996, s. 63). 
by dziecko powiedziało $J a$ i ustanawiało podmiot wobec ideału $\mathrm{Ja}^{10}$, z całym bagażem ideałów i ocen rodziców, w które od tej chwili będzie schwytane. A zatem w rozwoju dziecka kluczowy staje się porządek Symboliczny (językowy - jestem tym, kim mnie nazwano), wypierający porządek Wyobrażeniowy (obraz - jestem tym, jakim inni mnie widzą). Lacanowska faza lustra, podczas której dokonywana jest przez dziecko pierwotna identyfikacja, decyduje o jego następnych identyfikacjach. Osiągnięcie poziomu ideału Ja jest równoznaczne z przyjęciem wartości społecznych reprezentowanych przez Innego oraz potwierdzeniem, że podmiot osadzony jest już w języku. Warto jednak pamiętać, że oprócz ideału Ja Lacan sformułował również koncepcję idealnego Ja ${ }^{11}$, będącego efektem konstytuowania dziecięcego narcyzmu, również mającego swe źródło w fazie lustra i przynależącego do porządku Wyobrażeniowego. Idealne Ja odnosi się do tego, jak podmiot "powinien wyglądać” niestety w zgodzie z wyobrażeniem Innego na jego temat. Podmiot przyjmuje dla siebie wyobrażenie Innego i stwarza „swoje” Ja (ego), co oznacza, że asymiluje obcy, wytworzony przez kogoś obraz samego siebie. W rezultacie obraz, który jest reprodukowany przez podmiot, jest odpowiedzią na potrzebę Innego. Widzimy tu wyraźnie, na czym polega różnica pomiędzy porządkami Symbolicznym i Wyobrażeniowym i jak duże ma to znaczenie dla konstytuowania się podmiotowości i kształtowania tożsamości podmiotu. Różnicę tę wyznacza wejście w język albo uwięzienie w spojrzeniu Innego, będące na zawsze już dla podmiotu pułapką, z której wyzwolenie może przynieść co najwyżej wyprodukowanie symptomu będącego mechanizmem obronnym.

W horyzoncie troski o podmiot, jego identyfikacje i tożsamość interpretacja Lacana daje nadzieję, że to, co nazwane zostało kryzysem tożsamości, w rzeczywistości nie istnieje w takim wymiarze, jak zostaje przedstawiane.

10 W koncepcji Lacana ideat Ja reprezentuje ideał symboliczny jako adekwatność podmiotu z wartościami społecznymi, które powinny stać się rezultatem wejścia podmiotu w świat znaczących ustanawianych przez innych ludzi. Jednym słowem, ideat Ja jest ogółem znaczących oraz stosunków, które regulują ludzkim współżyciem (Węc, 2015).

11 Idealne Ja [Idealich, Lacanowskie i(a)] jest określeniem, w którym Lacan ukazuje podmiot pragnący znaleźć upodobanie w samym sobie poprzez odniesienie do związku ze spojrzeniem Innego. Odnosząc się do niemowlęcego pokawałkowanego obrazu ciała pozostawionego pod opieką matki, ukazuje idealne Ja jako źródło porządkujące pierwotny chaos podmiotowej egzystencji. Dziecko, obserwując obraz stworzony przez uczucia i reakcje rodziców, zdobywa stopniowo coraz większą kontrolę nad własnym ciałem (Węc, 2015). 
Niewykluczone też, że ten domniemany kryzys dotyczący pozornych identyfikacji jest w rzeczywistości obroną zasadniczej tożsamości podmiotu. Warto mieć na uwadze, że wciąż znajdujemy się w sferze porządku Wyobrażeniowego - a to pozwala nam uznać, że zarówno zakładany rozwój, jak i obawa przed kryzysem tożsamości są jedynie narracjami wypełniającymi dyskurs społeczny. Zatem antydialektyczna mentalność kultury, będąca zdominowaną przez obiektywizujące cele, ma tendencję do redukowania wszelkiej aktywności podmiotowej do bycia Ja(ego). Odnosząc się zatem do socjologicznych rekonstrukcji tożsamości, założenie, że „jestem uczniem” czy „jestem nauczycielem" - zapewne przedstawia mniej logicznych trudności niż twierdzenie „jestem człowiekiem”, które co najwyżej może oznaczać „jestem jak osoba, którą - rozpoznając, że jest człowiekiem - ustanawiam jako kogoś, kto może rozpoznać mnie jako człowieka" (Lacan, 1977).

Warto też przypomnieć, że Freudowska koncepcja człowieka opierała się na założeniu, że człowiek jako taki również podlega zasadzie uniwersalności. Dzieje się tak, gdyż jest to nie tylko człowiek funkcjonujący poprzez zapośredniczenie w kulturze, lecz także człowiek, który swą podmiotową strukturę konstytuuje poprzez biologiczne korzenie reprezentowane przez popęd oraz działanie Nieświadomego ukonstytuowanego przez język. Jest to również człowiek, który za wszelką cenę usiłuje nadać swojemu życiu sens bez względu na to, jak kształtuje się jego rzeczywistość i jak dalece jest świadomy własnej egzystencji. Uniwersalność tej koncepcji, zdaniem Freuda, miała swoje podłoże w działającym popędzie, któremu każdy podmiot podlega bez względu na czas i miejsce swojego życia. Równocześnie represywność kultury ma pewien stały wymiar, któremu człowiek musi się podporządkować, gdyż ukierunkowanie działania popędu jest konieczne do ukonstytuowania struktury podmiotu oraz jego relacji z Innym.

Dotyczy to również obecności podmiotu jako zakładanego przedmiotu oddziaływań wychowawczych. Tak zakładany (gotowy) podmiot to albo dążący do homeostazy organizm, albo „struktura regulacyjna”, na którą oddziałują bodźce zewnętrzne. Oddziaływania te zakładają istnienie podmiotu gotowego do samorealizacji poprzez aktualizowanie siebie i do autentyczne go przeżycia własnego wzrostu oraz rozwoju. Powracając do kwestii dziecka, zdaniem Lacana jest to sposób wejścia dziecka w świat, który ukazuje sposób, w jaki „prawidła” mowy wywierają skutki na całym podmiocie. Lacan, by uzasadnić stwierdzenie, że Nieświadome jest dyskursem Innego, posługuje się teorią afazji Jacobsona, która pozwala na stwierdzenie, że metafora i metonimia są miejscem, gdzie litera lokalizuje podmiot. Przy czym meto- 
nimia funkcjonuje jedynie w obrębie znaczącego, a metafora powstaje dzięki metonimii, odnajdując swój sens tam, gdzie jest nonsens. Dzięki metonimii można uchwycić podejście podmiotu do przedmiotu. Przyjmując, że rdzeń tożsamości wyznaczany jest przez obiekt $a$, musimy pamiętać, że reprezentuje on zarazem utracone imię podmiotu wypowiedzenia. Ten sam jednak obiekt a staje się źródłem niesamowitego, gdyby miał się pojawić w polu percepcji. Obiekt a, będąc podstawą lęku, jest zarazem obiektem, którego jedyną strukturą podmiotową jest efekt trwogi ${ }^{12}$.

Współczesna wiedza nie pozwala już na ignorowanie ponowoczesnej zmiany, która w nowoczesności reprezentowana była przez abstrakcyjną podmiotowość w kartezjańskim cogito ergo sum, w postaci absolutnej samowiedzy u Kanta. Samowiedzy ukazywanej poprzez „strukturę samoodniesienia poznającego podmiotu, który pochyla się nad sobą jako przedmiotem, aby niczym w zwierciadle - czyli właśnie »spekulatywnie« - uchwycić siebie" (Habermas, 2000, s. 29). Nowoczesność w koncepcji Foucaulta kończy się z chwilą przekroczenia przez kulturę progu, gdy „skończoność zaczęła być myślana w niekończącym się odwoływaniu do samej siebie” (Foucault, 2005, s. 134). Postrzeganie człowieka przez pryzmat skończoności wyznaczanej racjonalnością rozumu, znajdującego podtrzyma nie w empirycznych formach wiedzy, pozwala na stwierdzenie, że „kultura współczesna może myśleć o człowieku, ponieważ myśli o tym, co skończone, wychodząc od tego, co skończone" (Foucault, 2005, s. 134). Dyskurs ponowoczesności uwypukla pożegnanie ze spójnością podmiotu, zastąpioną dwuznacznością określaną przez byt i reprezentację symboliczną, która otwiera przed podmiotem możliwość poznania nie tylko z perspektywy bycia przedmiotem wiedzy. I jak podkreśla Foucault, miejscem analizy nie jest już sama reprezentacja, ale człowiek w swej nieskończoności i niedookreśleniu. Dyskurs ten przestaje być również podporządkowany zakładanej prawdzie, wprowadzając w strukturę niespójność i dwuznaczność ujawnioną przez język.

Jako pedagodzy nie możemy pozostać na tę wiedzę obojętni, jeżeli nasze działania mają mieć sens nie tylko w wymiarze skuteczności instytucjonalnej, ale nade wszystko w odniesieniu do tego, jak rzeczywiście może konstytuować się podmiot wraz z kształtującą się jego tożsamością w cyklu rozwojowym, którego jesteśmy świadkami. Tymczasem coraz częściej uwidacznia

12 Por. zilustrowana przez Freuda w artykule o niesamowitym, w którym bohater musiał uzupełnić lalkę własnymi oczyma, a oczy zostały przedstawione jako obiekty, które można kolekcjonować czy nawet zbywać (Freud, 1997, ss. 233-262). 
się przewaga porządku Wyobrażeniowego, w którym znaczący braku zostaje zastąpiony przez złudzenie posiadania tego, co dla Innego jest znaczące.

Konkludując, należy zadać pytanie, w jaki sposób działania wychowawcze mogą bronić się przed coraz częściej uwidaczniająca się w rzeczywistości heterologiczną transgresją - która nie tylko burzy struktury, ale również reprezentuje popęd śmierci wyznaczający działanie Realnego dla podmiotu. $\mathrm{Z}$ jednej strony ta heterologiczna koncepcja świata niesie wiele zagrożeń konstytuujących zdarzenia graniczne, ale z drugiej daje nadzieję, że rozsadzenie "starych" struktur podmiotu po zderzeniu z Realnym otwierać będzie przestrzeń na powstanie „nowego podmiotu”. Musimy mieć także świadomość, że dyskurs pedagogiczny nie daje wystarczających odpowiedzi na pytanie, jak wychowywać, i nie określa metody, jak postępować zwłaszcza w sytuacjach granicznych. Dzieje się tak z uwagi na samą strukturę podmiotu, który zawsze pozostaje wobec ukonstytuowanego w sobie braku i rozdarcia. Paradoksalnie tak zwane wychowanie tradycyjne, w którym nie uwzględniano podmiotowości dziecka, a więc nie zauważano obecności braku - stawiając dziecko w pozycji obiektu $a$ - było w praktyce wychowawczo i dydaktycznie bardziej skuteczne (przynajmniej pozornie). Skuteczność ta nie dotyczyła jednak rozwoju dziecka uwzględniającego jego szeroko rozumiany potencjał, ale miała wymiar adaptacyjny i funkcjonalny w stosunku do idealnych identyfikacji oraz mitu założycielskiego zbudowanego na wizji rozwoju społecznie użytecznego. Dając dziecku prawo do bycia podmiotem, prawo do pragnienia i prawo do domagania się - jako pedagodzy stanęliśmy oko w oko z tym, co dla podmiotu jest wyzwaniem, a dla nas staje się niemożliwością.

\section{Konkluzja}

Postęp nauki i tęsknota za poznaniem dążącym do wykluczania wszelkiego braku stały się synonimem naszych czasów, ukazując w efekcie pewną pustkę ukonstytuowaną wokół niemożliwości odnoszącej się do rozwoju, którego pożądamy, ale który staje się pustym znaczącym, żeby nie powiedzieć, że staje się wielkim nieobecnym współczesnego świata. Jednocześnie rozwój wiedzy na temat języka, ugruntowanie pojęć nieprzypadkowo zaczerpniętych z psychoanalizy przy równoczesnym zaawansowaniu rozwoju badań empirycznych - paradoksalnie unaoczniają nam konieczność uruchamiania działań, które nie odnajdywały swych reprezentacji w myśleniu i praktyce - ulokowanych $\mathrm{w}$ przestrzeni oddziaływania jednego podmiotu na inny podmiot. W tym sensie pytanie o pedagogikę jako naukę, która nie pozostaje jedynie na usługach 
polityki oświatowej, interesu rynków edukacyjnych, a przede wszystkim partykularnego dyskursu mistrza (nauczyciela, akademika czy tzw. lidera) stawia przed badaczami tej dyscypliny nowe wyzwania. Wyzwania te w czasie, określanym przez znaczace kryzysu zmuszają do przekraczania ram określanych dotąd przez poszukiwania krytycznych interpretacji czy wykluczania dyskursów nieobecnych. W tym też sensie dają nadzieję, że zmiana myślenia o podmiocie, jego tożsamości, genealogii i jego rozwoju - nie tylko jest możliwa, ale otwiera perspektywę „pedagogicznego rozumienia” ulokowanego poza obszarami złudnej wyobrażeniowości o sensie podmiotowej egzystencji nieustająco poddanej diagnozie, parametryzacji i swoistej inżynierii społecznej.

\section{Bibliografia}

Dąbrowski, K. 1989. Elementy filozofii rozwoju. Warszawa: Polskie Towarzystwo Higieny Psychicznej.

Derrida, J. i Roudinesco, E. 2016. Z czego jutro... Dialog. Warszawa: „Scholar”. Dybel, P. 2005. Czy psychoanaliza Lacana jest hermeneutyką? W: Lang, H. red. Język i nieświadomość. Gdańsk: Wydawnictwo słowo/obraz terytoria, ss. 5-31.

Fink, B. 2002. Kliniczne wprowadzenie do psychoanalizy Lacanowskiej. Teoria i technika. Warszawa: Wydawnictwo AZ.

Freud, S. 1997. Niesamowite. W: Pisma psychologiczne. Warszawa: Wydawnictwo KR, ss. 233-262.

Foucault, M. 2005. Stowa i rzeczy. Archeologia nauk humanistycznych. Gdańsk: Wydawnictwo słowo/obraz terytoria.

Gadamer, H.-G. 2008. Teoria, etyka, edukacja. Eseje wybrane. Warszawa: UW. Gusin, M. brw. Dwie koncepcje pragnienia: Lacan, Deleuze, Guattari. http:// www.jungpoland.org/pl/zbior-tekstow/dwie-koncepcje-pragnienia-lacandeleuze-guattari.html (18.08.2018).

Habermas, J. 2000. Filozoficzny dyskurs nowoczesności. Kraków: Universitas. Kwaśnica, R. 2007. Dwie racjonalności. Od filozofii sensu ku pedagogice ogólnej. Wrocław: Wydawnictwo Naukowe DSWE TWP.

Lacan, J. 1977. Aggressiveness in Psychoanalysis. W: Ecrits: A Selection. New York-London: W. W. Norton \& Co., Inc, pp. 8-29.

Lacan, J. 1981. The ethics of psychoanalysis. In: Miller J-A. ed. The Seminar of Jacques Lacan. New York - London: W. W. Norton \& Co.

Lacan, J. 1981a. The Four Fundamental Concepts of Psychoanalysis. In: 
Miller J.-A. ed. The Seminar of Jacques Lacan. New York - London: W. W. Norton \& Co.

Lang, H. 2005. Język i nieświadomość. Gdańsk: Wydawnictwo słowo/obraz terytoria.

Laplanche, J. i Pontalis, J.-B. 1996. Stownik psychoanalizy. Warszawa: WSiP. Malinowski, B. 2000. Jednostka, społeczność, kultura. Warszawa: PWN.

Marcuse, H. 1991. Człowiek jednowymiarowy. Badania nad ideologia rozwiniętego społeczeństwa przemystowego. Warszawa: PWN.

Melosik, Z. 1996. Tożsamość, ciało i władza. Teksty kulturowe jako(kon)teksty pedagogiczne. Poznań - Toruń: „Edytor”.

Melosik, Z. 2014. Kultura popularna i tożsamość młodzieży: w niewoli wtadzy $i$ wolności. Kraków: Oficyna Wydawnicza „Impuls”.

Melosik, Z. i Szkudlarek, T. 2013. Kultura, tożsamość i edukacja-migotanie znaczeń. Kraków: Oficyna Wydawnicza „Impuls”.

Nalaskowski, A. 2009. Pedagogiczne ztudzenia, zmyślenia, fikcje. Kraków: Oficyna Wydawnicza „Impuls”.

Pfister, O. 1931. Psychanaliza na ustugach wychowania. Lwów - Warszawa: Książnica - Atlas.

Rasiński, L. red. 2009. Język, dyskurs, społeczeństwo. Zwrot lingwistyczny w filozofii spotecznej. Warszawa: PWN.

Szałek, P. 2002. Melania Klein a krytyczna teoria społeczna C. F. Alforda, czyli o syntezie w filozofii. Nowa Krytyka. 13, ss. 237-256.

Węc, K. 2012. Psychoanaliza $w$ dyskursie psychoanalitycznym. Radykalność humanistyczna teorii i praktyki pedagogicznej. Konteksty nie tylko Lacanowskie. Toruń: Wydawnictwo Adam Marszałek.

Węc, K. 2013. Granice i transgresje wspótczesnego wychowania. Kontestacyjny wymiar pedagogiki krytycznej i jej praktyczne implikacje. Toruń: Wydawnictwo Adam Marszałek.

Węc, K. 2015. Granice i transgresje wspótczesnego wychowania. Psychoanaliza wobec kryzysu podmiotu. Wyd. II. Toruń: Wydawnictwo Adam Marszałek.

Węc, K. 2015a. Kliniczna hermeneutyka podejrzeń - topologiczna (bez)graniczność. Śladami Jacquesa Lacana. Kwartalnik Pedagogiczny. 2, ss. 185-203. Witkowski, L. 1988. Tożsamość i zmiana. Wstęp do epistemologicznej analizy kontekstów edukacyjnych. Toruń: UMK.

Witkowski, L. 2007. Między pedagogika, filozofia i kulturą. Studia, eseje, szkice. Warszawa: Instytut Badań Edukacyjnych \& Lech Witkowski. 
Witkowski, L. 2009. Rozwój i tożsamość w cyklu życia. Studium koncepcji Erika H. Eriksona. Łódź: WSEZ.

Witkowski, L. 2013. Przełom dwoistości w pedagogice polskiej: historia, teoria, krytyka. Kraków: Oficyna Wydawnicza „Impuls”.

Witkowski, L. 2015. Versus. 0 dwoistości strukturalnej faz rozwoju w ekologii cyklu życia psychodynamicznego modelu Erika H. Eriksona. Kraków - Dąbrowa Górnicza: Oficyna Wydawnicza „Impuls”.

\title{
Identity substitutes versus the genealogy and development of an individual. Between the mimetic function of anamorphosis and the figure of the Other
}

\begin{abstract}
Identity is one of the key categories that, due to cultural or ideological changes, has acquired specific interpretative representations in discourses and social space. These changes should lead to reflection on the current perception, as well as the reception of fundamental categories. This allows us to understand what contemporary identity is and what its embedding is in the sources of subjectivity understood in the perspective of interpreting Heidegger's "being-in-the-world" (Da sein) or Lacanian desire and relationship to the Other. The exemplification of these ontological and phenomenological representations is not accidental, nor is it the choice of a discourse called with the undisguised disapproval of today - a postmodern manner, recognized in its ignorance as (post) truth. The emergence of the cultural phenomena - presented in the text - is a deliberate presentation of the spectrum of this kind of hermeneutics, which allows to take into account contemporary understanding of man as a being entangled in the technological progress, determined by cognitive interest and subjected to emancipatory necessity as an inalienable right of the individual that marks its place in and for the world. On the other hand, we deal with an entity that is invariably involved in its own family history, existential fears, or individual complexes resulting from inadequacy of the surrounding reality and uncertain relations with the Other.
\end{abstract}

Keywords: pedagogy, Lacanian psychoanalysis, subject, identity, development, phenomena of culture, intercultural education 